\title{
The Issue of Studying Religious Tourism in Uzbekistan
}

\author{
Turaev Kuvonchbek Tohirovich ${ }^{1}$ \\ ${ }^{1}$ Department of Geography, Termez state university, Uzbekistan \\ Email:turaevt@tersu.uz
}

Turayeva Zarnigor Mamarasulovna

Departament of Interfaculties foreign languages, Termez state university, Uzbekistan

Email:zturayeva@tersu.uz

\begin{abstract}
The article notes that the research on religious tourism in Uzbekistan, the introduction of religious tourism as a new tourism industry, the fact that religious tourism in our country has its own specifics.
\end{abstract}

Keywords: holy shrine, religious tourism, geography of pilgrims, deification.

\section{INTRODUCTION}

After the independence of our country, great attention was paid to the study of religious tourism. It should be noted that during the former Soviet era, any process related to religion was neglected. For example, even local travelers and pilgrims did not have enough information about Imam Bukhari and his shrine [1; 2]. It should be noted that in 1956 the Center (Moscow) informed the Uzbek leadership that it was planned to take one of the prominent Lebanese politicians and public figures, Sheikh Nadim Imam Bukhari, to Uzbekistan. Authorities in Tashkent have called on the leaders of the Bukhara region to urgently put the shrine, the tomb of Imam Bukhari, in order. People in Bukhara say that the tomb is in Samarkand. When this task is given to the Samarkand leadership, they go in search of the grave. When they find out that the tomb is located in the village of Khartang, Payarik district, about 15-20 kilometers from Samarkand, it will be a ruined and neglected place. Samarkand will inform Tashkent and Tashkent will inform Moscow, and measures will be taken to bring it to an end. In the evening, the sheikh will visit the tomb of Hazrat Imam. When Sheikh Nadim saw the tomb, he knelt down, kissed the ground, and with great excitement knelt down towards the tomb of Hazrat Imam. Then he recites the Qur'an with tears in his eyes until dawn. In the morning, Sheikh Nadim realized why he had been brought in at night and wept over the dilapidated condition of the tomb and the mosque. It is not difficult to know how much attention is paid to religious issues in our country in the period from this process to independence.

Thanks to independence, the first President of our country Islam Karimov has repaired many shrines in Uzbekistan, such as Imam Bukhari, Imam Termizi and Hakim Termizi, Bahauddin Naqshband, Sufi Alloyar, Al Motrudi, Tsar Bakir Muhammad Zahid, Zangi ota in Samarkand region., the scope of geographers' research has also expanded.

\section{THE PURPOSE AND OBJECTIVES OF THE WORK}

The purpose of this work is to highlight the attention paid to religious tourism in Uzbekistan, the study of religious tourism by various experts. Disclosure and analysis of directions of religious tourism.

\section{MAIN PART}

Regarding religious and pilgrimage tourism in Uzbekistan, Professor AA Kayumov says that the flow of tourists 10-12 years ago was associated with the rich and diverse recreational resources of Uzbekistan, but in recent years this has been associated with the development of pilgrimage tourism [22]. 
Scientific researches on religious tourism in our country B.Navruz-Zoda, Ahmadaliev Yu.I., S.Abdullaev, N.Abdulahatov, S.Djuraeva, Z.Abidova, G.R.Pardaev, O.Khakimov, F.K.Kamilova and R .S.Samatov, V.N. Fedorko and others.

In particular, the research of Doctor of Economics, Professor Bakhtiyor Navruz-Zoda deeply studied the development of religious tourism in Uzbekistan. In particular, the scientist conducted research on the main purposes of pilgrimage in Uzbekistan, pilgrimage tourism, including the methods of marketing, geography, demographic, behavioral, psychological characteristics of pilgrims, the needs of the group of pilgrims. He has also made scientific developments on the use of hotel, restaurant, transport and guide services for pilgrims during their travels.

The scientist noted that the more convenient the infrastructure for visitors in the country, the more tourists visit. In particular, in his opinion, most of the hotels in our country are built in the European style, and they do not specialize for pilgrims. In our country, hotels should consist of two parts: the outer courtyard (for men) and the inner courtyard (for women). In addition, there are many restaurants and cafes in the country, but there are very few restaurants for visitors to eat honestly [6].

B.Navruz-Zoda also noted the expediency of creating a catalog of places of pilgrimage in Uzbekistan. It is necessary to include in this catalog a collection of colorful photographs of the holy places, to give clear explanations about them. The provision of such catalogs to incoming visitors creates the faith for the promotion of shrines in foreign countries, the development of tourism [2]. At the same time, it is advisable to establish travel agencies specializing in religious tourism. Tourism companies in our country specialize mainly in cultural and urban tourism [14;25]. They do not take into account the specifics of the religious pilgrimage. He put forward the idea that if we organize tourism-oriented marketing services in our country, the number of visitors will grow significantly.

An article on religious and pilgrimage tourism was first published in the Bulletin of the Geographical Society of Uzbekistan, one of the main scientific journals for geographers in Uzbekistan, in the 27 th issue of 2006 by G.R.

In it, it is expedient to pay attention to the following in the study of pilgrimages as geographically as possible:

Geographical location of shrines and their evaluation;

History of the establishment of shrines (in terms of social, economic, system of the time);

The natural geographical conditions of the places of pilgrimage, their differences and advantages from the surrounding areas;

Distribution of places of pilgrimage by regions, their causes;

The practical importance of shrines in attracting tourists;

Creating a map (map scheme) of places of pilgrimage and publishing booklets about them;

He wrote that it is necessary to determine whether the emergence of places of pilgrimage is associated with socio-economic, political processes.

Candidate of Geographical Sciences, Associate Professor S.Abdullaev published a number of scientific developments on theoretical and practical issues of pilgrimage tourism and sacred geography. According to the scientist, religious tourism is the most ancient type of tourism. His definition of religious tourism is as follows: "Travel is understood as a journey made for religious travelers to visit shrines outside the usual environment for educational and enlightenment purposes" [8]. He also cites two types of religious tourism, pilgrimage and excursion-enlightenment types.

Pilgrimage tourism includes all types of tourist services related to religion, various mystics, and events and traditions that cannot be explained.

The role of pilgrimage tourism in regional development concepts depends on a number of factors, which can be classified according to history and nature, as well as the human factor [18]. The existence of long-standing spiritual traditions is an important factor for the development of pilgrimage tourism. Unlike mass tourism, the main socio-economic advantage of pilgrimage tourism for the region is not the direct benefit, but the socio-psychological and pedagogical synergy of sacred programs for the population living in the region [8].

From the IX-X centuries, the expansion of irrigated areas in the mountainous areas of Uzbekistan and the changes that have occurred as a result of it [23], the most common way to correct the violations is the deification of the territories [21]. In particular, since that time the attention to the sacred places in the Fergana Valley has sharply increased. While the differences between the ethnocultural regions of the valley flow from the top to the bottom of the river basin, the ethno-ecological region and the corresponding "sacred places" are formed [11]. So, we can say that the ethno-ecological region and the pilgrimage-religious tourism region are formed in accordance with each other. In order to preserve the 
blessings of nature, scientists divide the sacred sites in the Shokhimardonsoy basin into 4 districts: Shohimardon, Vodil, Margilan and Yazyovan.

1. Shohimardon district; In the upper reaches of the river agriculture is less developed, mainly in the system of horticulture, animal husbandry and pilgrimage tourism services. There are more than 250 "shrines". This is mainly due to the degree of influence of nature components. For example, Chashma, Satkak, Arsif with fish, pigeons with birds, aquatic grasses are among them.

2. Vodil district; religious scholars can meet shrines called to'ra, sayid, sayinds. In particular, Haji ota is like Chinor ota.

3. Margilan district; These include shrines in the villages of Khanqiz, Chimgan, Arsif, Fayzabad, Yormozor, Satkak, and Naiman.

4. Yazyovan district; inaccessible to river water, springs and springs occupy the most remote parts of the basin, close to the surface. There are many solitary trees around the springs. These include shrines such as Yakkatut, Qayragach, Mingchinor.

Candidate of Historical Sciences, Associate Professor N.Abdulahatov conducted a dissertation on "The role of pilgrimage in the lifestyle of the people of the Fergana Valley" and defended it in 2008 [3]. S. Djuraeva's scientific works on "History of sacred shrines in Surkhandarya and their role in the religious and spiritual life of the population" [20] (2009), Z. Abidova on "Pilgrimages and shrines of the Khorezm oasis" (2018) are also related to pilgrimage tourism.

In our country, we can see the work of several scholars on the classification of religious tourism according to its characteristics. In the reviewed works, the works and articles of PhDs and foreign journals (scopus content) were considered.

The work being done in Uzbekistan to date on religious factors and the arousal of business interests can be divided into two historical-spiritual and economic-social directions:

1. Historical and spiritual direction, in which the motives and interests of the pilgrim, spiritual and cultural needs are studied. We meet them in the works of historical and ethnographers.

We can meet Bakhtiyor Navruz-Zoda and Zebiniso Navruz-Zoda in The Destination Marketing Development of Religious Tourism in Uzbekistan.

2. economic and social direction; opportunities for the population to earn extra income and increase employment. F.K.Kamilova and R.S.Samatovich (Kamilova 2007), B.Navruzzoda and Z.Navruzzoda (B.Navruz-Zoda and Z.Navruz-Zoda 2016), N.Ibragimov, A.Rakhmanov (B.Navruz- We can see in the works of Zoda, N.Ibragimov, A. Rakhmanov2017, 2018,), V.N. Fedorko (Fedorko V.N.2017) and others.

In this regard, FK Kamilova and RS Samatovich, when segmenting the market by geographical indications, it is necessary to take into account the same or similar preferences, which are determined by the fact that consumers live in this or that area. As a geographical segment, an entire country, country groups with some historical, political, national or religious unity can be considered [24].

In addition, the number of Russian Orthodox churches in the Republic is 38, which serves as a basis for considering the architecture of churches, the art of artists, the attractiveness of which as a monument of cultural heritage. The Church of Alexander Nevsky is one of them. These religious sites can serve as religious, pilgrimage, historical and cultural tourist sites in the countries of the region, including for foreign tourists with large populations of Russian and other Orthodox believers [4].

In our country, foreign tourists are mainly offered cultural and acquaintance types. They introduce historical, architectural, religious monuments and shrines, and demonstrate the lifestyle and culture of the local population.

He appreciates the role of religious tourism in the organization of pilgrimage tourism in Uzbekistan for representatives of multi-confessional [19] Zoroastrianism, Judaism, Buddhism, Islam. How to develop tourism in Uzbekistan?

\section{CONCLUSION}

It is important to introduce online systems that cover key services such as hotels, restaurants, airlines and train tickets, or national systems that allow extensive use of online systems.

Unlike self-organized pilgrims, pilgrims prefer to eat in public places or eat according to honest norms. It is very important that such offerings are located close to the holy places, so it is recommended to move such places (from fast food to the menu of pilgrims and even good places to eat).

Given that pilgrims travel in private or rented vehicles, it is important to implement parking management plans, as well as to provide campgrounds near the shrines. 
With the sharp increase in the number of people who prefer to use residential accommodation services, the demand for dormitories and rental housing will increase. Significant growth is expected in these sectors in the near future and the supply of such facilities should be increased.

The implementation of the above measures and the solution of the above conditions will ensure the attractiveness of the country for independent visitors from 76 visa-free countries, and thus ensure the competitiveness of tourism and travel in Uzbekistan.

\section{REFERENCES}

[1] Navruz-Zoda, Bakhtiyor and Navruz-Zoda, Zebiniso (2016) "The Destination Marketing Development of Religious Tourism inUzbekistan," International Journal of Religious Tourism and Pilgrimage: Vol. 4: Iss. 7, Article 3.doi:10.21427/D7G01XAvailable at: https://arrow.dit.ie/ijrtp/vol4/iss7/3

[2] Абдулахатов Н. Фарғона водийси ахолиси турмуш тарзида зиёратнинг ўрни. Тарих фанлари номзоди илмий даражасини олиш учун ёзилган диссертация автореферати. - Т., 2008.

[3] Федорко В.Н. География Русской православной церкви в странах Средней Азии // Ўзбекистон география жамияти ахбороти 50-жилд. Тошкент, 2017.

[4] Navruz-Zoda Bakhtiyor, Ibragimov Nutfillo, Rakhmanov Akmal THE DESTINATION MARKETING TOOLS FOR "SEVEN SUFI SAINTS OF NOBLE BUKHARA" PILGRIMAGE CLUSTER // Conference: International Religious Tourism And Pilgrimage Conference. 2017/06/27

[5] Bakhtiyor Negmatovich Navruz-Zoda, Nutfillo Ibragimov, Akmal Rakhmanov Perspectives on the Improvement of Uzbekistan as a Destination for Multi-Confessional Self-Organised Pilgrims // International Journal of Religious Tourism and Pilgrimage. 2018. №Volume 7.

[6] Абдуллаев С.И., Жанкабилов И.Х., Назаров М.Г Сакрал география - янги интеграл илмий йўналиш// Ўзбекистон география жамияти ахбороти 49-жилд. Тошкент, 2017.

[7] Abdullayev S.I., Murtazayev B.Ch. Ziyorat turizmi va sakral geografiyaning vazifalari // ЎЗБЕКИСТОН ГЕОГРАФИЯ ЖАМИЯТИ Х СЪЕЗДИ МАТЕРИАЛЛАРИ (ТошкенТ шахри, 2019 йил 6-7 декабрь. 22-24б.

[8] Ғ.Р.Пардаев, О.Хакимовлар томонидан Зиёратгох жойлар географиясини ўрганиш масаласи //

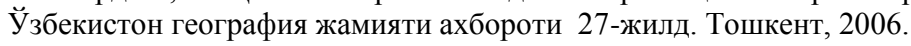

[9] Ахмадалиев Ю.И. Ер ресурсларидан фойдаланиш геоэкологияси. - Т.: Фанва технологиялар, 2014. 340 б.

[10] Ахмадалиев Ю.И., Исмоилов О. Экологик ва зиёрат туризми объектларини диний-хукуқий мухофаза қилиш усуллари // Ўзбекистонда туризм ва рекреацияни ривожлантиришнинг географик муаммолари ва имкониятлари Халқаро илмий-амалий конференция материаллари Чирчиқ шахри, 2019 йил 31-34б.

[11] Turaev.K.T., Turayeva Z.M. PERSPECTIVES FOR DEVELOPMENT OF PILGRIMAGE TOURISM FOR BUDDHIST REPRESENTATIVES IN THE REPUBLIC OF UZBEKISTAN (on the example of the Surkhandarya region) // International Journal of Psychosocial Rehabilitation, Vol. 24, Issue 04, 2020 ISSN: 1475-7192

[12] Turaev Kuvonchbek Tohirovich RELIGIOUS TOURIST FACILITIES OF HISTORICAL AND GEOGRAPHICAL STRUCTURE IN UZBEKISTAN // International Engineering Journal For Research \& Development, 5(3), 5.

[13] Исматов Д.А. Проблемы и перспективы социально-экономического развития моногородов Узбекистана // Perspectives of world science and education. Abstracts of V International Scientific and Practical Conference Osaka, Japan 29-31 January 2020. C. 405-408.

[14] Мирмахмудов Эркин Рахимжанович, Абдумуминов Баходир Одинаевич ПОСТРОЕНИЕ ЦИФРОВОЙ МОДЕЛИ ГОРНОГО УЧАСТКА ПОТОПОГРАФИЧЕСКИМ КАРТАМ // НауКа, культура и образование. - 2020. - №2 (46). - С. 59-63.

[15] Mirmakhmudov E., Safarov E., Fazilova D., Abdumuminov B. Modification of the reference frame of Uzbekistan topographic maps based on the GNSS. United Nations/Nepal Workshop on the Applications of Global Navigation Satellite Systems , Kathmandu, Nepal, 12 - 16 December 2016.

[16] Kholmatov Z., Abdumuminov O., Abdumuminov B., Bahramov I. NATIONAL MODEL OF ECONOMY DEVELOPMENT IN UZBEKISTAN // European Journal of Research and Reflection in Educational Sciences. - 2019. - №Vol. 7 No. 12. - C. 1028-1030.

[17] Rajabov F.T. Dynamics and Regional Features of Agricultural Production. In the Republic of Uzbekistan // International Journal of Psychosocial Rehabilitation, Vol. 24, Issue 02, 2020 ISSN: 1475-7192 https://www.psychosocial.com/article/PR200425/10119/

[18] https://www.psychosocial.com/article/PR260046/13225/

[19] http://diss.natlib.uz/uz-Cyrl-UZ/ResearchWork/OnlineView/33312

[20] Rajabov F.T. Farms of Uzbekistan: development and regional features // Positioning of Russia and its regions in the modern world: socio-geographical analysis and forecast. Materials of the international scientific conference (Fifth Annual Scientific Assembly of ARGO). - St. Petersburg, 2014 .-S. 152-157.

[21] Қаюмов А.А., Қаюмова И.К. Туризмни халқаро миқёсида ва Ўзбекистонда ривожлантиришнинг хозирги холати // Ўзбекистонда туризм ва рекреацияни ривожлантиришнинг географик муаммолари ва имкониятлари Халқаро илмий-амалий конференция материаллари Чирчиқ шахри, 2019 йил 90946. 
[22] Rajabov F.T. Dependence of meat production on the potential of fodder production in Uzbekistan // EPRA International Journal of Research and Development Volume: 5 Issue: 5 | May 2020

[23] Камилова Ф.К, Р.С.Саматов Туризм маркетинг ўкув кўлланма Тошкент-2007 Б

[24] Ismatov J.A Placement of cities of Uzbekistan on major water and economic regions // ACADEMICIA: An International Multidisciplinary Research Journal Vol. 10 Issue 5, May 2020. -S.1518-1521.

[25] Musaev D.A Analysis of the research on teaching geography to blind students // ACADEMICIA: An International Multidisciplinary Research Journal Vol. 10 Issue 5, May 2020. -S.1680-1685.

[26] Soliev A.S., Kurbonov Sh.B., Razhabov F.T. Shifts in the sectoral and territorial structure of the economy of Uzbekistan // Socio-economic geography: Bulletin of the Association of Russian Geographers-Social Studies (ARGO). No. 5 - Rostov-on-Don, 2016 .-- S. 209-218.

[27] Tojieva Z.N., Dusmanov F.A. Reproduction and its regional differences in the Republic of Uzbekistan // International Journal of Psychosocial Rehabilitation, Vol. 24, Issue 04, 2020. ISSN: 1475-7192. P. 41614171. 